\title{
A Common Approach to the Synthesis of Monocyclofarnesyl Sesquiterpenes
}

\author{
Paola Ciceri $^{\mathrm{a}, \mathrm{c}}$, F.W. Joachim Demnitz* ${ }^{\mathrm{b}}$, Márcia C.F. de Souza ${ }^{\mathrm{b}}$, \\ and Maik Lehmann ${ }^{a, \mathrm{~d}}$ \\ ${ }^{a}$ Preclinical Research, Novartis Pharma AG, CH-4002 Basel, Switzerland \\ ${ }^{\mathrm{b}}$ Departamento de Química Fundamental, Universidade Federal de Pernambuco, \\ Cidade Universitária, 50.670-901 Recife - PE, Brazil \\ ${ }^{c}$ Present address: Pharmaton S. A., Via Mulini, CH-6934 Bioggio, Switzerland. \\ ${ }^{\mathrm{d}}$ Praktikant from the University of Marburg, Germany
}

Received: August 10, 1998

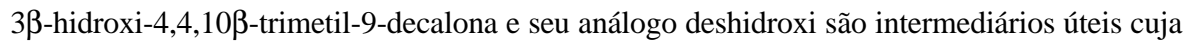
oxidação de Baeyer-Villiger e subsequente homologação por dois carbonos propicia a construção rápida do esqueleto monociclofarnesólico. Os estudos sintéticos visando a uma variedade de sesquiterpenos são discutidos.
\end{abstract}

$3 \beta$-hydroxy-4,4,10 $\beta$-trimethyl-9-decalone and its dehydroxy analogue are useful intermediates whose Baeyer-Villiger oxidation and subsequent two-carbon homologation provides a quick entry into the monocyclofarnesyl skeleton. The synthetic approaches to a variety of sesquiterpenes are discussed.

Keywords: Baeyer-Villiger reaction, monocyclofarnesyl, sesquiterpenes, aplysistatin, ambilol, 7-hydroxy-6,11-cyclofarnes-3(15)-en-2-one, ancistrofuran, synthesis

\section{Introduction}

Sesquiterpenes having a monocyclofarnesyl skeleton $\mathbf{1}$ are ubiquitous in nature ${ }^{1}$.

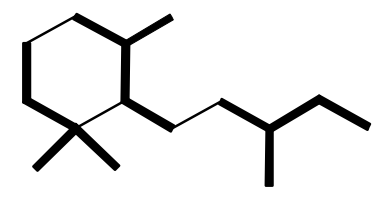

1

In such natural products the trimethylsubstituted ring is often additionally functionalized in the $\mathrm{C} 3$-neopentyl position (e.g. 2 - 4) as well as at the methyl-bearing tertiary carbon atom $\left(\right.$ e.g. $\left.2-7^{\#}\right)$. In view of the placement of functionality in the well known trans-decalones $\mathbf{8 \mathbf { a } ^ { 2 }}$ and $\mathbf{8 b}^{2 \mathrm{a}, 3}$ it was quite obvious that they could serve a role as common starting materials for many monocyclofarnesylsesquiterpenes syntheses. More specifically, Baeyer-Vil- liger oxidation of the B-ring ketone would provide $\mathbf{9 a} / \mathbf{b}$ containing the correctly functionalized carbocyclic ring with appropriate stereochemistry for a variety of natural products. Introduction of two carbons atoms $\alpha$ to the lactone-carbonyl (alternatively in the open chain form) would complete the construction of the monocyclofarnesyl skeleton, (Scheme 1).

We are currently engaged in using this strategy for the synthesis of several sesquiterpenes. Recently we disclosed the total synthesis ${ }^{4}$ of $( \pm)$-farnesiferol-C $\mathbf{2}$ which closely followed along these lines. Here we would like to present a review and update on our ongoing efforts to synthesize aplysistatin $\mathbf{4}^{5}$, ambilol-A $\mathbf{5}^{\# 6}, 7$-hydroxy-6,11-cyclofarnes3(15)-en-2-one $\mathbf{6}^{7}$ and ancistrofuran $7^{8}$.

\section{Results and Discussion}

At the outset, the abovementioned Baeyer-Villiger oxidation of the 9-decalone system deserves some comment.

\# Ambilol-A $\mathbf{5}$ is not a sesquiterpene. However, its' C1-C15 "monocyclofarnesyl-subskeleton" is clearly amenable to synthesis according to the strategy under discussion. 
The apparently straightforward B-ring ketone oxidation to the $\varepsilon$-lactones $9 \mathbf{a} / \mathbf{b}$ bore some surprises. Thus, performing the oxidation on the hydroxy ketone $\mathbf{8 b}$ provided the un- conventional product $\mathbf{1 0}$ arising through participation of the $3 \beta$-hydroxy group. Substrates bearing an acid labile $\mathrm{OH}$ protecting group which is removed under the Baeyer-Vil-

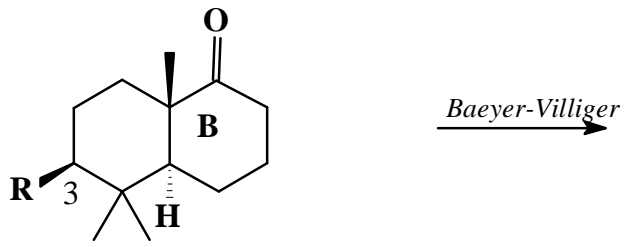

8a: $\mathrm{R}=\mathrm{H} ; \mathbf{8 b}: \mathrm{R}=\mathrm{OH}$

8c: $\mathrm{R}=\mathrm{OAc} ; \mathbf{8 d}: \mathrm{R}=\mathrm{OCOPh}$
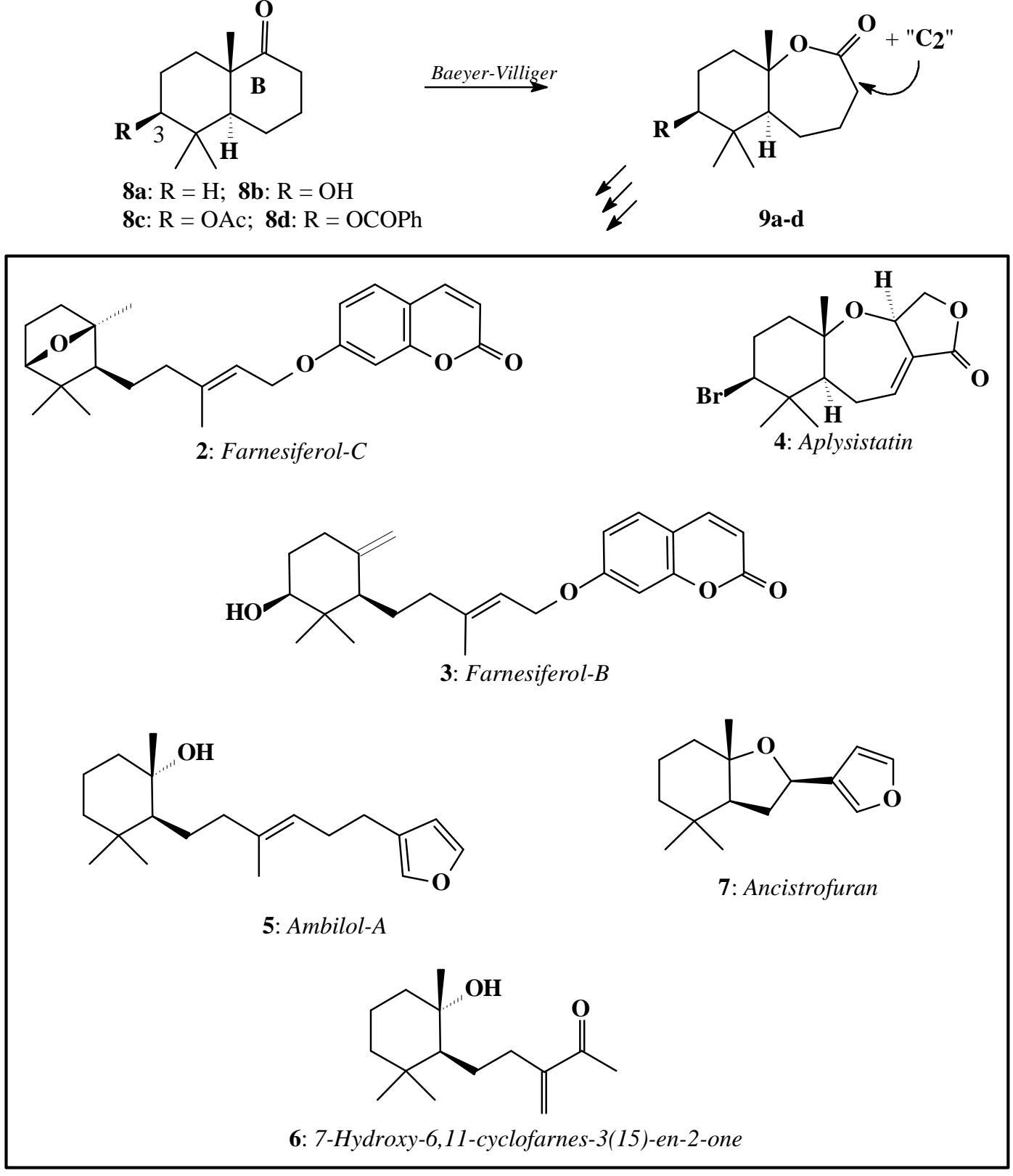

Scheme 1 .

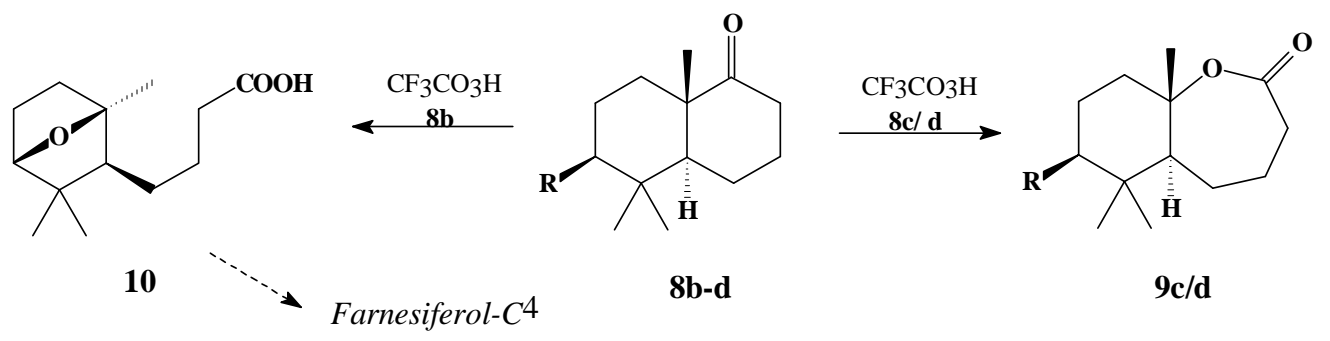


liger reaction conditions also resulted in $\mathbf{1 0}$ whereas the stable $3 \beta$-acyloxy derivatives $\mathbf{8 c / d}$ gave the expected lactones $9 \mathrm{c} / \mathbf{d}^{4}$.

The mechanism of this rearrangement is currently the subject of investigation. Thus, the question of whether transanular oxa-ring formation occurs stepwise $(\mathbf{8 b} \rightarrow \mathbf{9 b}$ $\rightarrow \mathbf{1 2} \rightarrow \mathbf{1 0}$ ) or in a concerted fashion with direct participation of the 3ß-hydroxyl $(\mathbf{8 b} \rightarrow \mathbf{1 3} \rightarrow \mathbf{1 0})$ is being addressed by us by means of a computational analysis of the thermodynamic and kinetic aspects of the possible reaction paths $^{9}$ (see Scheme 2).

The 3-methylene analogue 8a gave an equally surprising product upon Baeyer-Villiger oxidation in acidic media $\left(\mathrm{CF}_{3} \mathrm{CO}_{3} \mathrm{H} / \mathrm{CF}_{3} \mathrm{CO}_{2} \mathrm{H} / \mathrm{CH}_{2} \mathrm{Cl}_{2}\right)$, namely the hydroxy spirolactone $16^{10}$. Controlled buffered conditions $\left(\mathrm{CF}_{3} \mathrm{CO}_{3} \mathrm{H} /\right.$ $\mathrm{CF}_{3} \mathrm{CO}_{2} \mathrm{H} / \mathrm{Na}_{2} \mathrm{HPO}_{4} / \mathrm{CH}_{2} \mathrm{Cl}_{2} / 0{ }^{\circ} \mathrm{C}, 72 \%$ or $m$-CPBA/Na$\mathrm{HCO}_{3} / \mathrm{DCE} / \mathrm{RT}$-reflux, $74 \%$ ) were necessary to avoid the formation of $\mathbf{1 6}$ and secure the desired lactone 9a. We propose, that in acidic media 9a proceeds via olefin 14 and epoxide 15 to 16 (see Scheme 3).

Whilst the interesting rearrangement in the Baeyer-Villiger reaction of $\mathbf{8 b}$ giving $\mathbf{1 0}$ allowed the synthesis of farnesiferol-C $\mathbf{2}^{4}$, the other (lactone) products in hand (9a and $9 \mathbf{c} / \mathbf{d}$ ) open the way for our synthetic approaches to the natural products 4 - 7.

The decalones $\mathbf{8 a} / \mathbf{b}$ are prepared ${ }^{2,3}$ from the well known Wieland-Miescher ketone $17^{11}$ which has served as starting material in many syntheses ${ }^{2 a, 2 b, 3 a, 4,12}$. The advent of the availability of the Wieland-Miescher ketone in enantiomerically pure form ${ }^{13}$ has widened its scope so as to permit the synthesis of natural products in their optically pure state ${ }^{14}$. We have recently found an improved and very

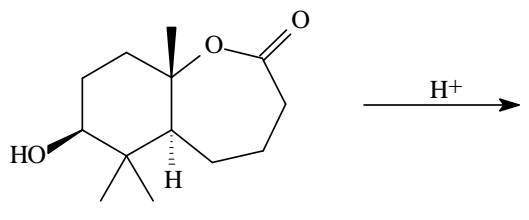

9b

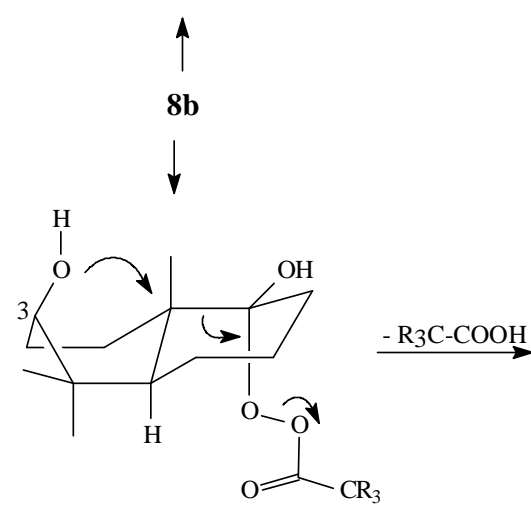

13 efficient method for a rapid, selective and high-yielding preparation of the monoketal $\mathbf{1 8}$ of this diketone, uncontaminated by bisketal (which is extremely tedious to separate! ${ }^{15}$. In summary, these developments allowed an expedient preparation of the common decalone intermediates 8a-d in appreciable quantity along established lines ${ }^{3 b}$ and in optically pure form.

The decalone 8d was oxidised using trifluoroperoxyacetic acid / trifluoroacetic acid in dichloromethane providing exclusively the lactone 9d in $75 \%$ yield. The final two carbons of the monocyclofarnesyl skeleton were then incorporated by alkylation of the lithium enolate (LDA/TMEDA/THF/-78 ${ }^{\circ} \mathrm{C}$ ) with 1,2-dibromoethyl ethyl ether, cleanly providing the ethoxyethylated product 19d (79\%) as a 2:1 mixture of diastereoisomers. Although the stereochemistry at the alkylated carbon in 19d was of no consequence for subsequent synthetic manipulations, the alkylation was shown to have occurred exclusively from
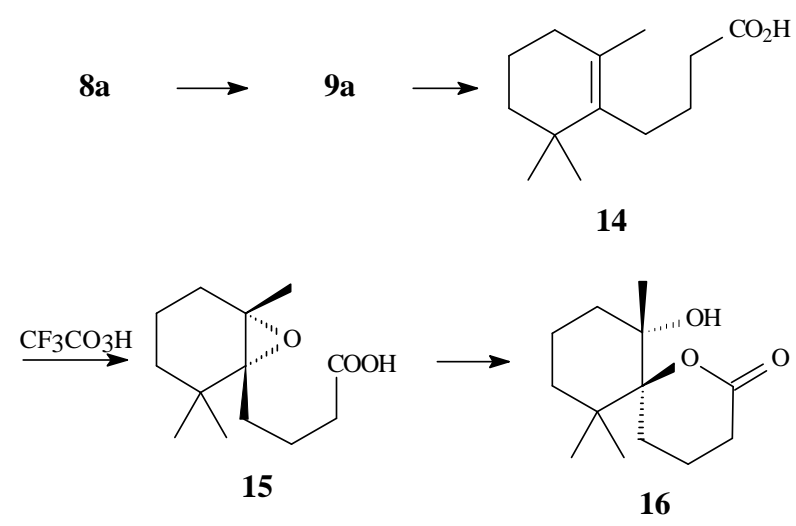

Scheme 3.<smiles>C[C]1CC[C@@H](O)C(C)(C)[C@@H]1CCCC(=O)O</smiles>

12

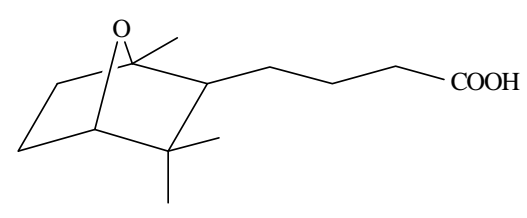

Scheme 2. 
the $\alpha$-face (opposite to the angular methyl substituent) by means of an X-ray crystal structure of the minor diastereomer; (Fig. 1).

With a conclusive structure proof of the C-15 monocyclofarnesyl skeleton now in hand, the mixture of diastereomers 19d was treated with $5 \%$ aqueous $\mathrm{K}_{2} \mathrm{CO}_{3}$ in $\mathrm{THF} /$ acetone resulting in a one-pot conversion to the hydroxy butenolide 20d involving $\varepsilon$-lactone hydrolysis, butyrolactone formation of the intermediate $\gamma$-bromo acid and $\beta$-ethanol elimination thus completing the overall transformation of decalone $\mathbf{8 d}$ to the advanced sesquiterpene intermediate 20d in just three steps and $47 \%$ overall yield. The hydroxybutenolides $\mathbf{2 0}$ serve as intermediates for aplysistatin $\mathbf{4}^{17}$ (from 20d) and ancistro-<smiles>[R]C1CCCC2=CC(=O)CC[C@@]21C</smiles>

17: Wieland-Miescher ketone, $\mathrm{R}=\mathrm{O}$

18: $\mathrm{R}=$ ethylene ketal

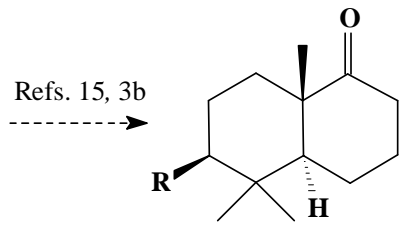

8a: $\mathrm{R}=\mathrm{H}$

8b: $\mathrm{R}=\mathrm{OH}$

8d: $\mathrm{R}=\mathrm{OCOPh}$

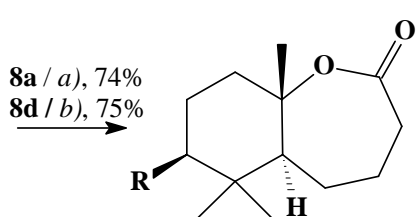

$9 a / d$

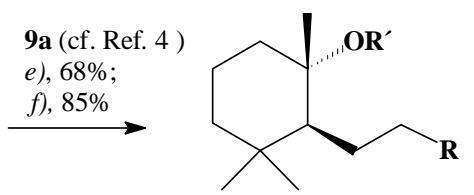

24: $\mathrm{R}=\mathrm{CH}=\mathrm{CPh}_{2}$

25: $\mathrm{R}=\mathrm{COOH}$

26: $\mathrm{R}=\mathrm{C}(\mathrm{OH}) \mathrm{MeCH}=\mathrm{CH}_{2}$ $\mathrm{R}^{\prime}=\mathrm{TBDMS}$ 9a / d), $88 \%$

9d / c), $79 \%$<smiles>[R]C1CC[C@]2(C)OC(=O)[C@H]([C@@H](O)CBr)CC[C@@H]2C1(C)C</smiles>

$19 a / d$

19d $/ g), 80 \%$

19a / $h), 62 \%$

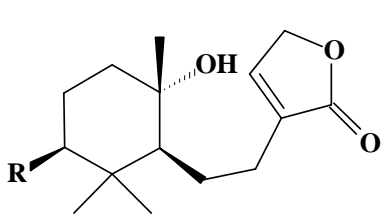

20a/d

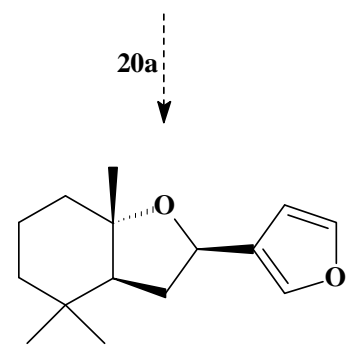

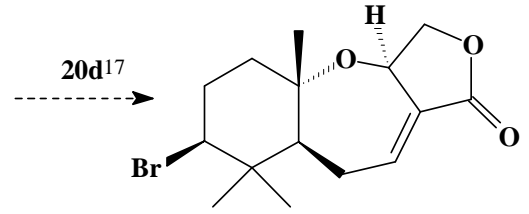

4: Aplysistatin<smiles>C/C(=C\CBr)CC[C@H]1C(C)(C)CCC[C@]1(C)O</smiles>

27

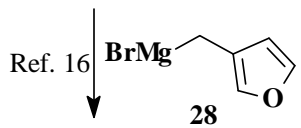

5: Ambilol-A

\section{7: Ancistrofuran}

Scheme 4. a) $\underline{m}$-CPBA/DCE/NaHCO $3 / \mathrm{RT}$-rfx.; $b$ ) $\mathrm{CF}_{3} \mathrm{CO}_{3} \mathrm{H} / \mathrm{CF}_{3} \mathrm{CO}_{2} \mathrm{H} / \mathrm{Na}_{2} \mathrm{HPO}_{4} / \mathrm{CH}_{2} \mathrm{Cl}_{2} / \mathrm{RT}$; ) LDA/THF/TMEDA/EtO-CHBrCH $2 \mathrm{Br} /-78{ }^{\circ} \mathrm{C}-\mathrm{RT}$; d) $\mathrm{LDA} / \mathrm{LiCl} / \mathrm{THF} / \mathrm{DME} / \mathrm{EtO}-\mathrm{CHBrCH}_{2} \mathrm{Br} /-78{ }^{\circ} \mathrm{C}-\mathrm{RT} ; e$ ) $\left.\mathrm{PhMgBr} / \mathrm{Et}_{2} \mathrm{O} / 0{ }^{\circ} \mathrm{C}-\mathrm{RT} ; f\right)$ p-TsOH$/ \mathrm{CHCl}_{3} / \mathrm{RT} ; g$ ) $\mathrm{K}_{2} \mathrm{CO}_{3} / \mathrm{H}_{2} \mathrm{O} / \mathrm{THF} / \mathrm{acetone} / 60{ }^{\circ} \mathrm{C} ; h$ ) $\mathrm{K}_{2} \mathrm{CO}_{3} / \mathrm{H}_{2} \mathrm{O} / \mathrm{THF} / 60{ }^{\circ} \mathrm{C}$. 


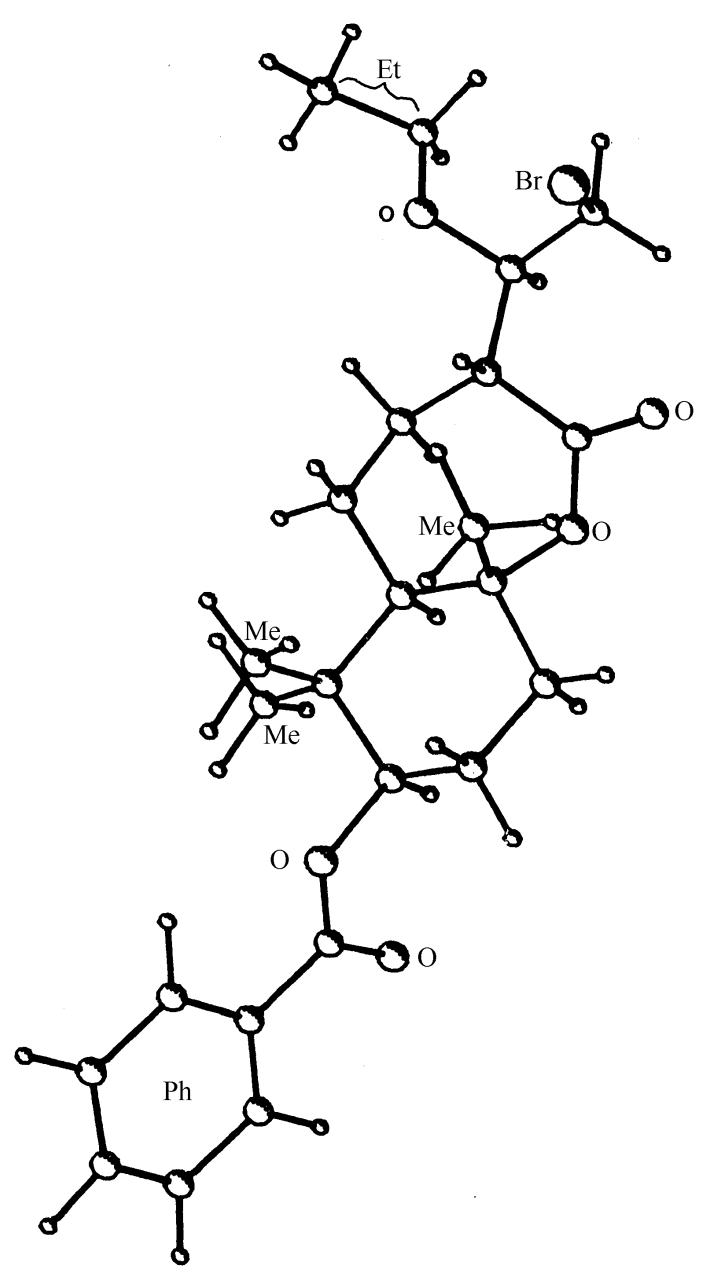

Figure 1.

furan 7 (from 20a). The latter compound was prepared in a similar fashion from 8a in $40 \%$ overall yield (see Scheme 4).

Several routes from 20a to ancistrofuran can be envisaged. Our initial results indicate, that phenylselenation of the dienolate derived from the TBDMS-ether derivative gives, albeit in low yield (amongst other products) the deconjugated phenylseleno derivative 21. Clearly, oxidative elimination of this compound will provide the exocyclic $\alpha, \beta$-unsaturated lactone 22, deprotection and ring closure of which would result in the butenolide $\mathbf{2 3}$ which has been previously converted to ancistrofuran ${ }^{8 \mathrm{~g}}$. Therefore the transformation of $\mathbf{2 1}$ into $\mathbf{2 3}$ would complete a formal total synthesis of ancistrofuran. At the time of writing, our efforts in this regard are continuing and we will report the results at an appropriate opportunity. Owing to the fact, that the absolute configuration of ancistrofuran is not known, we are in a position to answer this question by virtue of the use of chiral material stemming from the (+)-Wieland-Miescher ketone.
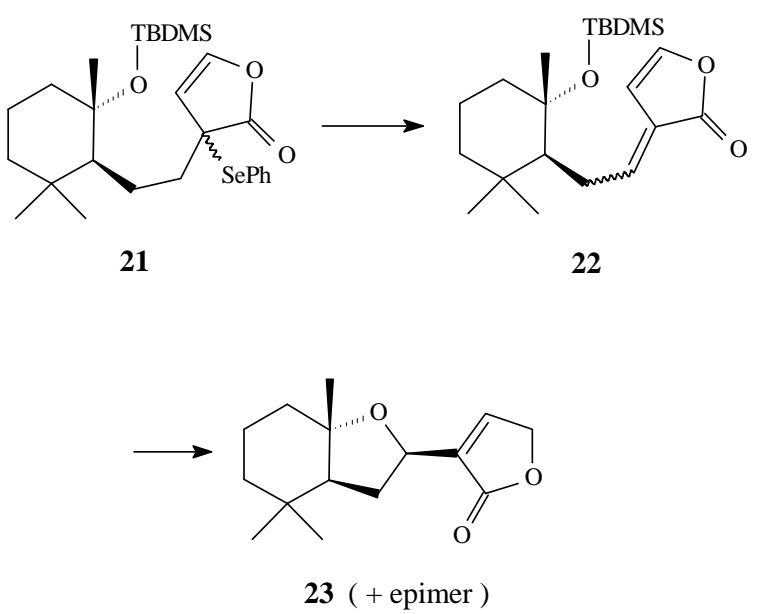

If the introduction of the final two carbon atoms of the monocyclofarnesyl skeleton is delayed until a later point in the synthetic sequence, one may open the way to farnesiferol-C $\mathbf{2}^{4}$, ambilol-A 5 and 7-hydroxy-6,11-cyclofarnes$3(15)$-en-2-one $\mathbf{6}^{17}$. In a procedure analogous to that used for the synthesis of farnesiferol- $C,{ }^{4}$ a standard BarbierWieland approach $\left(\mathrm{PhMgBr} / \mathrm{Et}_{2} \mathrm{O}\right.$ then $\left.p-\mathrm{TsOH} / \mathrm{CHCl}_{3}\right)$ provided diphenylolefin $\mathbf{2 4}$ from lactone $\mathbf{9 a}$. At the time of deadline for submission we are involved in the oxidative cleavage of this compound to the hydroxy acid $\mathbf{2 5}$. Treatment of this intermediate with methyllithium followed by TBDMS protection and vinylmagnesium bromide addition (final two monocyclofarnesyl carbons) should result in the allylic alcohol $\mathbf{2 6}^{4}$. It then remains to prepare the allylic bromide $\mathbf{2 7}^{4}$ and couple it with the 3-methylfuran Grignard reagent $\mathbf{2 8}^{16}$ in order to complete the synthesis of ambilolA.

\section{Acknowledgments}

We would like to thank Novartis AG / Basel / Switzerland for financial support. M.C.F. d. S. thanks the Departamento de Assuntos Estudantis of the University for a scholarship.

\section{References}

1. Fraga, B.M. Nat. Prod. Rep. 1998, 15, 73; 1997, 14, 145.

2.a) Snitman, D.L.; Tsai, M.-Y.; Watt, D.S.; Edwards, C.L.; Stotter, P.L. J. Org. Chem. 1979, 44, 2838; b) Cocker, J.D.; Halsall, T.G. J. Chem. Soc. C 1957, 3441; c) Sondheimer, F.; Elad, D. J. Am. Chem. Soc. 1957, 79, 5542; d) Ototani, N.; Kato, T.; Kitahara, Y. Bull. Chem. Soc. Jpn. 1967, 40, 1730; e) Ohloff, G.; Giersch, W.; Schulte-Elte, K.-H.; Vial, C. Helv. Chim. Acta 1976, 59, 1140.

3. a) Sondheimer, F.; Elad, D. J. Am. Chem. Soc 1958, 80, 1967; b) Kalvoda, J.; Loeffel, H. Helv. Chim. Acta 1957, 40, 2340; c) King, F.E.; Ritchie, C.F.; Simmons, C.J. Chem. Ind. 1956, 1230. 
4. Demnitz, F.W.J.; Philippini, C.; Raphael, R.A. J. Org. Chem. 1995, 60, 5114.

5. Pettit, G.R.; Herald, C.L.; Allen, M.S.; von Dreele, R.B.; Vanell, L.D.; Kao, P.Y.; Blake, W. J. Am. Chem. Soc. 1977, 99, 262. For syntheses see: Hoye, T.R.; Kurth, M.J. J. Am. Chem. Soc. 1979, 101, 5065; White, J.D.; Nichiguchi, T.; Skeean, R.W. J. Am. Chem. Soc. 1982, 104, 3923; Shieh, H.M.; Prestwich, Tetrahedron Lett. 1982, 4643.

6. Walker, R.P.; Faulkner, D.J. J. Org. Chem. 1981, 46, 1098.

7. Habtemariam, S.; Gray, A.I.; Waterman, P.G. J. Nat. Prod. 1993, 56, 140. For synthesis see: Yajima, A.; Takikawa, H.; Mori, K. Liebigs Ann. Chem. 1996, 891.

8. a) Baker, R.; Briner, P.H.; Evans, D.A. J. Chem. Soc., Chem. Commun. 1978, 410; b) Evans, D.A.; Baker, R.; Briner, P.H.; McDowell, P.G. Proc. $8^{\text {th }}$ Int. Congr. Int. Union Study Soc. Insects, Centre Agric. Publ., Wageningen, Netherlands, p. 46.; c) Baker, R.; Briner, P.H.; Evans, D.A. Adv. Pestic. Sci., Ed. Geissbuehler, H.; Pergamon Press, Oxford, 1978, vol. 2, 330. For syntheses see: d) Baker, R.; Briner, P.H.; Evans, D. A. J. Chem. Soc., Chem. Commun. 1978, 981; e) Baker, R.; Ravenscroft, P.D.; Swain, C.J. J. Chem. Soc., Chem. Commun. 1984, 74; f) Baker, R.; Cottrell, I.F.; Ravenscroft, P.D.; Swain, C.J. J. Chem. Soc., Perkin Trans. I. 1985, 2463; g) Hoye, T.R.; Caruso, A.J. J. Org. Chem. 1981, 46, 1198; h) Saito, A.; Matsushita, H.; Kaneko, H. Agric. Biol. Chem. 1986, 50, 1309; i) Mori, K.; Suzuki, N. Liebigs Ann. Chem. 1990, 287.

9. Demnitz, F.W.J.; Simas, A.M.; Ventura, E. Ongoing; to be published.

10. Demnitz, F.W.J.; Freiberger, S.; Weber, H.-P. Helv. Chim. Acta 1995, 78, 887.

11. Wieland, P.; Miescher, K. Helv. Chim. Acta 1950, 33, 2215; Wendler, N.L.; Slates, H.L.; Tischler, M. J. Am.
Chem. Soc. 1951, 73, 3816; Ramachandran, S.; Newman, M.S. Org. Synth. Coll. Vol. V 1973, 486.

12. Sondheimer, F.; Elad, D. J. Am. Chem. Soc. 1959, 81, 4429; Ghera, E.; Sondheimer, F. Tetrahedron Lett. 1964, 3887; Danieli, N.; Mazur, Y.; Sondheimer, F. Tetrahedron 1967, 23, 509; Spencer, T.A.; Weaver, T.D.; Villarica, R.M.; Friary, R.J.; Posler, J.; Schwartz, M.A. J. Org. Chem. 1968, 33, 712; Stork, G.; Singh, J. J. Am. Chem. Soc. 1974, 96, 6181; Danishefsky, S.; Cain, P.; Nagel, A. J. Am. Chem. Soc. 1975, 97, 380; Avery, M.A.; Tanabe, M.; Crowe, D.F.; Detre, G.; Peters, R.H.; Chong, K.M. Steroids 1990, 55,59 .

13. Gutzwiller, J.; Buchschacher, P.; Fürst. A. Synthesis 1977, 167; Buchschacher, P.; Fürst. A. Org. Synth. 1986, 63, 37; Buchschacher, P.; Fürst. A.; Gutzwiller, J. Org. Synth., Coll. Vol. VII 1988, 368; Harada, N.; Sugioka, T.; Uda, H.; Kuriki, T. Synthesis 1990, 53.

14. Ruppert, J.; Eder, U.; Wiechert, R. Chem. Ber. 1973, 106, 3636; Gutzwiller, J.; Meier, W.; Fürst. A. Helv. Chim. Acta 1977, 60, 2258; Kametani, T.; Suzuki, K.; Nemoto, H. J. Chem. Soc., Chem. Commun. 1979, 1127; Kametani, T.; Suzuki, K.; Nemoto, H. J. Org. Chem. 1980, 45, 2204; Li, Y.; Nassim, B.; Crabbé, P.J. J. Chem. Soc., Perkin Trans. I 1983, 2349; Harada, N.; Kohori, J.; Uda, H.; Nakanishi, K.; Takeda, R. J. Am. Chem. Soc. 1985, 107, 423; Ihara, M.; Toyota, M.; Fukumoto, K.; Kametani, T. J. Chem. Soc., Perkin Trans. I 1986, 2151; Kim, M.; Gross, R.S.; Sevestre, H.; Dunlap, N.K.; Watt, D.S. J. Org. Chem. 1988, 53, 93; Harada, N.; Sugioka, T.; Ando, Y.; Uda, H.; Kuriki, T. J. Am. Chem. Soc. 1988, 110, 8483.

15. Ciceri, P.; Demnitz, F.W.J. Tetrahedron Lett. 1997, 38, 389.

16. Tanis, S.P. Tetrahedron Lett. 1982, 23, 3115.

17. Our work involving the synthesis of this natural product will be the subject of a future paper. 